\title{
Adjusting the Minigrafting Technique Applied to Citrus by Using Rootstocks Grown in vitro
}

\author{
Maria Inês S. Mendes ${ }^{1}$, Antônio S. Souza ${ }^{2}$, Maria Angélica P. C. Costa ${ }^{1}$, Walter S. Soares Filho ${ }^{2}$, \\ Abelmon S. Gesteira ${ }^{2} \&$ Honorato P. Silva Neto ${ }^{2}$ \\ ${ }^{1}$ Centro de Ciências Agrárias Ambientais e Biológicas, Universidade Federal do Recôncavo da Bahia, Cruz das \\ Almas, BA, Brazil \\ ${ }^{2}$ Embrapa Mandioca Fruticultura, Cruz das Almas, BA, Brazil \\ Correspondence: Maria Inês S. Mendes, Centro de Ciências Agrárias Ambientais e Biológicas, Universidade \\ Federal do Recôncavo da Bahia, Cruz das Almas, BA, Av. Rui Barbosa, 710, Centro, Brazil. Tel: \\ 55-759-8128-9348. E-mail: inessm.123@gmail.com
}

Received: April 23, 2019

Accepted: May 27, $2019 \quad$ Online Published: July 31, 2019

doi:10.5539/jas.v11n11p193

URL: https://doi.org/10.5539/jas.v11n11p193

\begin{abstract}
Techniques applied to promote citrus propagation are of extreme relevance, since they assure high yield rates, as well as high genetic and phytosanitary quality. The aim of the present research is to assess the vegetative growth and survival of citrus cultivars subjected to different rootstocks through minigrafting in order to generate identical to the parents. Minigrafting of apical segments ( 1 and $2 \mathrm{~cm} \mathrm{long})$ of 'Clementine' tangerine budded onto rootstocks of citrandarins 'Indio' and 'Riverside' and of the combination between varieties 'Pera' sweet orange, 'Sunki Madarin' tangerine and 'Santa Cruz Rangpur' lemon budded onto rootstocks of citrandarins 'Indio', HTR-069 and LRF $\times(\mathrm{LCR} \times \mathrm{TR})-005$ were evaluated. Assessments were conducted in greenhouse 120 days after the experiment were installed. The use of $2 \mathrm{~cm}$ long segments facilitates minigrafting adherence to smaller caudal apices. The rootstock of HTR-069 presented the best survival responses among the assessed crowns. Rootstock of citrandarin 'Indio' enabled the best crown length development and graft diameter. Based on the results, minigrafting can be a new option for citrus propagation.
\end{abstract}

Keywords: citrus spp., tissue culture, propagation, grafting

\section{Introduction}

Citrus are traded through grafting, since the rootstock provides many characteristics favorable to citrus crown when it comes to the quality of fruits, to tolerance and resistance to weather and phytopathological adversities (Andrade \& Martins, 2003). Besides, citrus youthfulness is an issue that can be overcome through bud grafting from growing plants, even onto juvenile rootstock (Carlos, Stuchi, \& Donadio, 1997). This technique is also essential for the propagation of citrus triploid varieties, mainly tangerine varieties, moreover, it enables the propagation of genotypes that do not produce seeds or that are tripod.

Grafting is a multiplication method, which consists in planting tissues from two different parents in justaposition to generate a new and single individual from them. Plant rootstock provides the root system and the basal area of the trunk, whereas the other plant provides the shoot, which develops from a fragment (scion and bud) and is genetically identical to the mother plant. However, the rootstock has influence over the crown, and the crown influences the rootstock, as well as the weather, soil, plagues and the management influence the crown rootstock combination (Cunha Sobrinho et al., 2013).

Besides the conventional grafting technique used for the commercial propagation of genus Citrus (L.), one can find the apex micrografting technique, which consists in grafting caudal apices in micropropagated rootstocks cultivated in vitro. Navarro, Roistacher and Murashige (1975) developed this technique to generate citrus plants without systemic diseasesoften transmitted through conventional grafting.

Minigrafting, which is a variation of the apex micrografting, has been used in some new species such as as rubber trees (Hevea brasiliensis Muell. Arg.) (Lemos Filho et al., 1994), south american mahogany (Swietenia macrophylla King) (Kalil Filho, Hoffmann, \& Tavares, 2001), Prosopis alba Griseb. (Ewens \& Felker, 2003), mate (Ilex paraguariensis A. St.-Hill.) (Wendling \& Hoffmann, 2005), passion fruit (Passiflora edulis Sims f. 
flavicarpa Deg. and P. mucronata Lam.) (Alexandre et al., 2013; Oliari et al., 2016), walnut (Juglans regia L.) (Farsi et al., 2016) and guava (Psidium guajava L.) (Campos et al., 2017), as a new vegetative-propagation strategy.

This technique is based on a multiplication system, in which an apical segment cultivated in vitro is cleft grafted onto a rootstock grew in greenhouse. Besides promoting large scale clonal propagation of high-quality phytosanitary seedlings, this technique has the great advantage of reducing plant susceptibility to system diseases as it happens with propagation through conventional grafting. When this technique is compared to micrografting, it presents higher adherence and great healing rates, fact that makes it easier to graft and generate seedlings in a shorter period of time (Wendling \& Hoffmann, 2005). Micrografting is a technique mainly accessed to eliminate viruses in citric species (Ohta et al., 2011; Chae et al., 2013; Sanabam et al., 2015); however, few studies in the literature have assessed the minigrafting technique applied to citric species.

Thus, the aim of the present study was to assess the vegetative growth and survival of 'Pera' sweet orange [C. sinensis (L.) Osbeck], 'Sunki Mandarin' [C. sunki (Hayata) hort. ex Tanaka], 'Clementina' tangerine ( $C$. clementina hort. ex Tanaka) and 'Santa Cruz Rangpur' lemon (C. limonia Osbeck) through minigrafting to propagate plants identical to the mother-plants budded onto rootstocks of citrandins 'Indio' and 'Riverside' and of hybrids HTR-069 and LRF $\times(\mathrm{LCR} \times \mathrm{TR})-005$.

\section{Method}

The present research was conducted in the greenhouse and on Tissue Culture Laboratory of Embrapa Cassava and Fruticulture, located in Cruz da Almas County, Bahia State, Brazil. Citrandarins 'Indio' and 'Riverside' as well as hybrids HTR-069 and LRF $\times(\mathrm{LCR} \times \mathrm{TR})-005$ which resuled from crossing involving 'Sunki Mandarin' tangerine [C. sunki (Hayata) hort. ex Tanaka], 'Santa Cruz Rangpur' lemon (C. limonia) and Poncirus trifoliata (TR), were selected as rootscks for the experiment. Crown variables 'Pera' sweet orange, 'Sunki Mandarin' and 'Clementine' tangerines and 'Santa Cruz Rangpur' lemon were also selected to the research.

\subsection{Rootstock Obtainment}

Fruits from rootstocks of citrandarins 'Indio' and 'Riverside', and of hybrids HTR-069 and LRF $\times(\mathrm{LCR} \times$ TR)-005 were collected in the Active Bank of Citrus Germplasm (BAGC), in the fields of Embrapa Cassava and Fruitculture. The seeds were removed from the fruits, they were washed and sown in plastic tubes $\left(120 \mathrm{~cm}^{3}\right)$ filled with approximately $100 \mathrm{~g}$ of commercial substrate Vivatto ${ }^{\circledR}$ and stored in greenhouse. Rootstock transplantation to pots $(20 \mathrm{~cm} \times 25 \mathrm{~cm} \times 0.20 \mathrm{~cm})$ filled with $1 \mathrm{~kg}$ of Vivatto ${ }^{\circledR}$ happend when plants reached 8 $\mathrm{cm}$ tall approximately at the age of four months, since it would allow better plant nutrition and development. Rootstocks were used in minigrafting when their stem diameter reached approximately $2 \mathrm{~mm}$.

\subsection{Crown Variaties Generated in in vitro}

Seeds of varieties 'Pera' sweet orange, 'Sunki Mandarin' and 'Clementine' tangerines and 'Santa Cruz Rangpur' lemon were collected in BAGC, in the field. Seeds were romoved from the fruits in the laboratory; next, they were washed and their coat was removed. Seeds were disinfected in $70 \%$ etanol for five minutes and in $0.5 \%$ sodium hypochlorite solution (with two drops of Tween ${ }^{\circledR} 20$ ) for 20 minutes. This procedure was followed by three washings in autoclaved distilled water. After the seeds were disinfected, they were distributed in test tubes (14 $\mathrm{cm}$ height and $2.3 \mathrm{~cm}$ diameter) fillied with $10 \mathrm{~mL}$ of culture medium WPM (Lloyd \& Mccown, 1980), supplemented with $30 \mathrm{~g} \mathrm{~L}^{-1}$ of sucrose, solidified with $2 \mathrm{~g} \mathrm{~L}^{-1}$ of Phytagel ${ }^{\circledR} ; \mathrm{pH}$ was adjusted to 5.7-5.8. The test tubes were stored at temperature $27 \pm 1{ }^{\circ} \mathrm{C}$, at photon flux density $30 \mu \mathrm{mol} \mathrm{m} \mathrm{m}^{-2} \mathrm{~s}^{-1}$, under 16 hours photoperiod.

\subsection{Size of the Apical Segment Adopted to Minigrfting Performed With Citrus Cultures}

Apical segments ( 1 to $2 \mathrm{~cm}$ long) of 'Clemntine' tangerine were budded onto rootstocks of citrandarins 'Indio' and 'Riverside'. The study followed a completely randomized design at $2 \times 2$ factorial arrangement (two apical segments and two rootstocks), with 20 repetitions per treatment; each plot was composed of one rootstock and one apical segment. The seedlings (approximately $6 \mathrm{~cm}$ tall) were sectioned after 90 days. Two different experiments were based on apical segment removal and on minigrafting.

Rootstocks (approximately 20 to $30 \mathrm{~cm}$ tall and approximate diameter $2 \mathrm{~mm}$ ) were cut on the apical region and the leaves were removed only three superior leaves were left in each plant. A longitudinal slit approximately 0.5 $\mathrm{cm}$ depth was made in the stem. Minigrafting was conducted under in vivo condition; two wedge shaped cuts were made at the basis of the apical segment, which was inserted in the longitudinal slit of the rootstock. The parts in contact to one another were wrapped in parafilm to fully seal the grafting area in order to avoid tissue dehydration and to facilitate the union of the two parts. The minigrafted plants were covered with transparent plastic bags tied in the basis of the rootstock to generate a wet chamber. The samples were stored in a grill at 
$\pm 27{ }^{\circ} \mathrm{C}$, on average. The plastic bags were untied after 30 days and removed one week later. The parafilm was kept until the parts were completely united after 60 days, on average. The buds in the rootstocks were eliminated in order to avoid nutritional imbalance, which could hamper the graft.

Apical segments of tangerine 'Clementina' measuring 1 and $2 \mathrm{~cm}$ length and the rootstock of citrandarins 'Indio' and 'Riverside' were used in the first experiment, which followed a completely randomized design at factorial arrangement $2 \times 2$ (two sizes of apical segments and two rootstocks-each part has an apical segment and a rootstock), with 20 repetitions per treatment. The experiment was conducted in the vegetation house and assessed after 120 days.

\subsection{Crown-rootstock Combination in Minigrafting Applied to Citrus Cultures}

Apical segments (1.5 cm long) of 'Pera' sweet orange, 'Sunki Mandarin' tangerine and 'Santa Cruz Rangpur' lemon were minigrafted onto rootstocks of citrandarin 'Indio', and of hybrids HTR-069 and LRF $\times(\mathrm{LCR} \times$ TR)-005. The study followed a completely randomized design at $3 \times 3$ factorial arrangement (three crowns and three rootstock varieties) with 15 repetitions per treatment. Each experimental plot encompassed one rootstock and one apical segment.

\subsection{The Minigrafting Procedure}

Rootstocks (20 and $30 \mathrm{~cm}$ tall and diameter approximately $2 \mathrm{~mm}$ ) were used in both experiments. They were subjected to decaptation in the apical area and to defoliation; only three upper leaves were left in each plant. A longitudeinal slit was opened on the stem (approximately $0.5 \mathrm{~cm}$ deep); subsequently, mingrafting was peformed in vitro. Two wedge shaped cuts were made on the basis of the apical segment, which was inserted in the longitudinal slit of the rootstock. In order to make adherence easier and to avoid tissue dehydration, parts in contact to each other were raped with parafilm to fully seal the graft area. Minigrafted plants were covered with transparent plastic bags, which were labled on the basis of the rootstock in order to form a humid chamber. Plants were, then, stored at mean temperature $\pm 27^{\circ} \mathrm{C}$. The plastic bags were losed 30 days later and removed 1 week after they were losed. The parafilm was kept until both parts were fully adhered to each other, 60 days later, on average. Buds on the rootstocks were eliminated to avoid nutritional unbalances capable of influencing rootstock buds.

\subsection{Statistical Analysis}

Evaluations started 120 days after the experiments were installed in the greenhouse. The following variables were assessed: graft survival rate, number of leaves, crown length $(\mathrm{cm})$, graft diameter $(\mathrm{mm}) 1 \mathrm{~cm}$ above the grafted region and leaf blade length $(\mathrm{cm})$ of the largest leaf in the upper third of the plant. Data were subjected to analysis of varienace in software SISVAR, version 5.5 (Ferreira, 2011) at 5\% of significance level. Means were compared through Tukey test at $5 \%$ probability. Values recorded for number of leaves were transformed into $\sqrt{\mathrm{x}+1}$ in order to comply with assumption about the analysis of variance.2.3.1 Sample Size, Power, and Precision Along with the description of subjects, give the mended size of the sample and number of individuals meant to be in each condition if separate conditions were used. State whether the achieved sample differed in known ways from the target population. Conclusions and interpretations should not go beyond what the sample would warrant.

\section{Results}

\subsection{Size of the Apical Segment in Minigrafting Applied to Citrus Culture}

Based on the herein assessed experimental conditions, survival rates of different rootstocks were similar: $32.50 \%$ and 35\%, respectively, for citrandarins 'Indio' and 'Riverside'. There was no difference between the assessed genotypes. With regard to variation in the size of the apical segment, the highest survival rate was observed when apical segment length of $2 \mathrm{~cm}$ was used (55\%) (Table 1). 
Table 1. Survival rate of 'Clementina' tangerine (Citrus clementina hort. ex Tanaka) minigrafted onto rootstocks of citrandarins [C. sunki (Hayata) hort. ex Tanaka $\times$ Poncirus trifoliata (L.) Raf.] 'Indio' and 'Riverside', 120 days after minigrafting with 1 and $2 \mathrm{~cm}$ long apical segments

\begin{tabular}{ll}
\hline Rootstock & Survival rate (\%) \\
\hline Citrandarin 'Indio' & 32.50 \\
Citrandarin 'Riverside' & 35.00 \\
\hdashline Apical segment length & 12.50 \\
$1 \mathrm{~cm}$ & 55.00 \\
$2 \mathrm{~cm}$ & 15.00 \\
Rootstock $\times$ Apical segment length & 50.00 \\
Citrandarin 'Indio' $\times 1 \mathrm{~cm}$ & 10.00 \\
Citrandarin 'Indio' $\times 2 \mathrm{~cm}$ & 60.00 \\
Citrandarin 'Riverside' $\times 1 \mathrm{~cm}$ & \\
Citrandarin 'Riverside' $\times 2 \mathrm{~cm}$ & \\
\hline
\end{tabular}

The survival rate ranged from 10 to $60 \%$ when the interaction between rootstock and apical segment size was assessed (Table 1). This failure was partially attributed to fungal contamination in the apical segments.

The highest survival rates were recorded for rootstocks of citrandarin 'Riverside' (60\%) and 'Indio' (50\%) minigrafted with $2 \mathrm{~cm}$ long segments. Survival rates dropped to $10 \%$ (citrandarin 'Riverside') and 15\% (citrandarin 'Indio') when $1 \mathrm{~cm}$ long segments were used (Table 1).

The herein presented table depicts analysis of variance results, which did not show significant effects at $5 \%$ probability $(\mathrm{p}<0.05)$ in any of the assessed variables due to isolated factors and to lack of interaction between them (Table 2).

Table 2. Analysis of variance applied to variables number of leaves (NL), crown length (CL), rootstock diameter (RD) and leaf balde length (LBL) of 'Clementine' tangerine minigrafted onto rootstocks of citrandarins 'Indio' and 'Riverside', 120 days after minigrafting application by means of apical segments ( 1 and $2 \mathrm{~cm} \mathrm{long)}$

\begin{tabular}{llllll}
\hline Source of Variation & DF & NL & CL $(\mathbf{c m})$ & RD $(\mathbf{m m})$ & LBL $(\mathbf{c m})$ \\
\hline Rootstock (RS) & 1 & $0.01^{\mathrm{ns}}$ & $5.47^{\mathrm{ns}}$ & $0.00^{\mathrm{ns}}$ & $0.39^{\mathrm{ns}}$ \\
Apical segment size (ASS) & 1 & $0.10^{\mathrm{ns}}$ & $20.78^{\mathrm{ns}}$ & $0.04^{\mathrm{ns}}$ & $14.75^{\mathrm{ns}}$ \\
RS $\times$ ASS & 1 & $0.01^{\mathrm{ns}}$ & $1.85^{\mathrm{ns}}$ & $0.05^{\mathrm{ns}}$ & $0.34^{\mathrm{ns}}$ \\
Mean & & 8.18 & 6.53 & 1.85 & 6.55 \\
Error & & 0.57 & 19.05 & 0.09 & 19.05 \\
CV $(\%)$ & & 26.39 & 66.73 & 16.72 & 53.83 \\
\hline
\end{tabular}

Note. $\mathrm{ns}=$ non-significant $(\mathrm{p}<0.05)$.

The used rootstock and the size of the apical segments did not influence the numner of leaves, rootstock length, rootstock diameter and leaf blade length when variety 'Clementine' tangerine was grafted onto the rootstock of citrandarins 'Indio' and 'Riverside' (Table 3).

Table 3. Means recorded for variables number of leaves (NL), crown length (CL), rootstock diameter (RD) and leaf blade length (LBL) of 'Clementine' tangerine minigtafted onto rootstocks of citrandarins 'Indio' and 'Riverside' 120 days after minigrafting by means of 1 and $2 \mathrm{~cm}$ long apical segments

\begin{tabular}{lcccc}
\hline & NL & CL (cm) & RD (mm) & LBL (cm) \\
\hline Rootstock & & & & \\
Citrandarin 'Indio' & $8.23 \mathrm{a}$ & $7.01 \mathrm{a}$ & $1.84 \mathrm{a}$ & $4.95 \mathrm{a}$ \\
Citrandarin 'Riverside' & $8.14 \mathrm{a}$ & $6.11 \mathrm{a}$ & $1.85 \mathrm{a}$ & $4.71 \mathrm{a}$ \\
\hdashline Apical segment size & & & & \\
$1 \mathrm{~cm}$ & $8.80 \mathrm{a}$ & $8.38 \mathrm{a}$ & $1.93 \mathrm{a}$ & $6.38 \mathrm{a}$ \\
$2 \mathrm{~cm}$ & $8.04 \mathrm{a}$ & $6.12 \mathrm{a}$ & $1.83 \mathrm{a}$ & $4.48 \mathrm{a}$ \\
\hline
\end{tabular}

Note. Means followed by the same letter did not statistically differ from each other in the Tukey test $(\mathrm{p}<0.05)$. 
After 120 days, it was possible observing well established connection between rootstock and graft. There was a small callus in the graft region, which evidenced the perfect adherence between both parts (Figure 1).

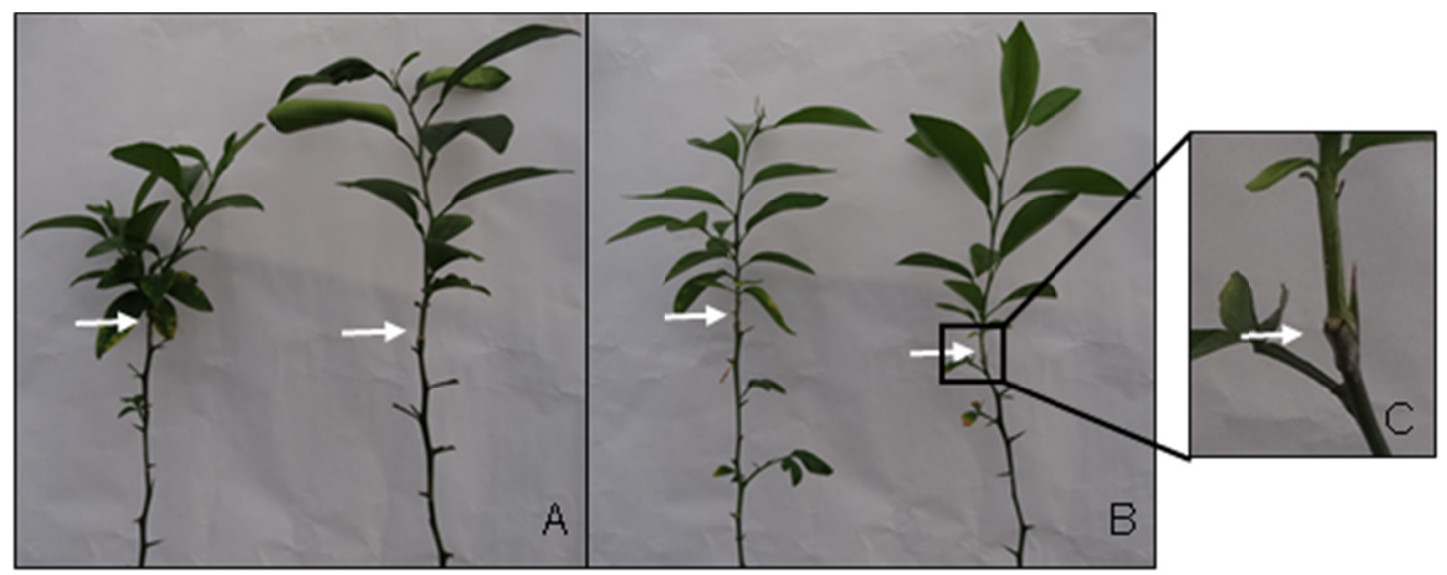

Figure 1. 'Clementina' tangerine (Citrus clementina hort. ex Tanaka) minigrafted onto citrandarins [C. sunki (Hayata) hort. ex Tanaka $\times$ Poncirus trifoliata (L.) Raf.] 'Indio' (A) and 'Riverside' (B) 120 days after minigrafting with 1 and $2 \mathrm{~cm}$ long apical segments. (C) Detail of the adherence.

The arrow shows the minigrafting area

\subsection{Crown Minigraft Combination in Minigrafting Applied to Citrus Culture}

By assessing factors crown and rootstock in separate, it was observed that plants grafted onto trifoliolate hybrid HTR-069 recorded the highest survival rate $62 \%$ success. Survival results recorded for citrandarins 'Indio' and LRF $\times($ LCR $\times$ TR) -005 were similar: $40 \%$ and $42 \%$, respectively, in plants grafted onto these hybrids (Table 4 )

With regard to the crown effect, 'Santa Cruz Rangpur' lemon presented the highest survival rate; this variety was followed by 'Pera' sweet orange and by 'Sunki Mandarin' tangerine.

Table 4. Survival rates of 'Pera' orange [Citrus sinensis (L.) Osbeck], 'Sunki Mandarin' tangerine [C. sunki (Hayata) hort. ex Tanaka] and 'Santa Cruz Rangpur' lemon (C. limonia Osbeck) in citrandarin rootstocks [C. sunki $\times$ Poncirus trifoliata $(\mathrm{L}$.) Raf.] 'Indio', trifoliate hybrid HTR-069 and LRF $(C$. jambhiri Lush. $) \times[\mathrm{LCR}(C$. limonia $)$ $\times$ TR $(P$. trifoliata $)]-005,120$ days after minigrafting

\begin{tabular}{|c|c|}
\hline Rootstock & Survival (\%) \\
\hline Citrandarin 'Indio' & 40.00 \\
\hline HTR-069 & 62.22 \\
\hline $\mathrm{LRF} \times(\mathrm{LCR} \times \mathrm{TR})-005$ & 42.22 \\
\hline \multicolumn{2}{|l|}{ Crown } \\
\hline 'Pera' sweet orange & 46.67 \\
\hline 'Sunki Mandarin’ tangerine & 35.55 \\
\hline 'Santa Cruz Rangpur' lemon & 62.22 \\
\hline \multicolumn{2}{|l|}{ Rootstock $\times$ Crown } \\
\hline Citrandarin 'Indio' $\times$ 'Pera' sweet orange & 53.33 \\
\hline Citrandarin 'Indio' × 'Sunki Mandarin' tangerine & 20.00 \\
\hline Citrandarin 'Indio' × 'Santa Cruz Rangpur' lemon & 46.67 \\
\hline HTR-069 × 'Pera' sweet orange & 60.00 \\
\hline HTR-069 $\times$ tree 'Sunki Mandarin' tangerine & 53.33 \\
\hline HTR-069 × 'Santa Cruz Rangpur’ lemon & 73.33 \\
\hline $\mathrm{LRF} \times(\mathrm{LCR} \times \mathrm{TR})-005 \times$ 'Pera' sweet orange & 26.67 \\
\hline $\mathrm{LRF} \times(\mathrm{LCR} \times \mathrm{TR})-005 \times$ 'Sunki Mandarin' tangerine & 33.33 \\
\hline $\mathrm{LRF} \times(\mathrm{LCR} \times \mathrm{TR})-005 \times$ 'Santa Cruz Rangpur' lemon & 66.67 \\
\hline
\end{tabular}


The interaction between rootstock and varieties used as crown recorded the highest survival rates in the combination HTR-069 /'Santa Cruz Rangpur' lemon (73.33\%), which was followed by LRF $\times$ (LCR $\times$ TR)-005/'Santa Cruz Rangpur' lemon, (66.67\%) and by HTR-069/'Pera' sweet orange (60\%) (Table 4).

Table 5 shows highly significant differences at $1 \%$ probability $(\mathrm{p}<0.01)$ in copmparison to the rootstock factor in all variables, except for leaf blade length. With regard to the used crwon variety, only rootstock diameter had some influence over the leaf balde length. There was no significant difference in the interaction between rootstock and the used crown varieties in any of the assessed variables.

Table 5. Analysis of variance applied to number of leaves (NL), crown length (CL), rootstock diameter (RD) and leaf blade length (LBL) of three different citrus crown cultuivars budded onto three rootstocks 120 days after minigrafting

\begin{tabular}{llllll}
\hline Source of Variation & DF & NL & CL (cm) & RD (mm) & LBL $(\mathbf{c m})$ \\
\hline Rootstock (RS) & 2 & $13.26^{* *}$ & $638.95^{* *}$ & $3.24^{* *}$ & $7.93^{\text {ns }}$ \\
Crown variety (CV) & 2 & $0.29^{\mathrm{ns}}$ & $159.04^{\mathrm{ns}}$ & $2.41^{* *}$ & $85.08^{* *}$ \\
$\mathrm{RS} \times \mathrm{CV}$ & 4 & $0.56^{\mathrm{ns}}$ & $26.20^{\mathrm{ns}}$ & $-3,26.10^{7 \mathrm{~ns}}$ & $0.62^{\mathrm{ns}}$ \\
Mean & & 16.62 & 16.74 & 2.37 & 8.34 \\
Error & & 0.71 & 66.49 & 0.20 & 7.01 \\
CV $(\%)$ & & 20.70 & 48.71 & 18.81 & 31.75 \\
\hline
\end{tabular}

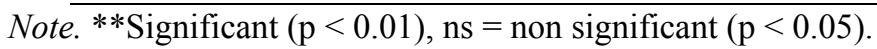

The highest means recorded for number of leaves (23 and 18.96) were observed in rootstocks of citrandarins 'Indio' and LRF $\times(\mathrm{LCR} \times \mathrm{TR})-005$, respectively. Citrandarin 'Indio' also recorded the longest crown length, graft diameter and leaf blade length results (Table 6).

With regard to crown variety, 'Pera' sweet orange presented the largest rootstock diameter, $2.76 \mathrm{~mm}$, on average. The longest leaf blade length. $10.10 \mathrm{~cm}$ and $8.48 \mathrm{~cm}$, on average, were recorded for crown varieties 'Pera' sweet orange and 'Santa Cruz Rangpur' lemon, respectively (Table 6).

Table 6. Means recorded for variables number of leaves (NL), crown length (CL), rootstock diameter (RD) and leaf blade length (LBL) of three different citrus crown cultivars 120 days after minigrafting, based on rootstock and on the used crown variety

\begin{tabular}{lcccc}
\hline & NL & CL (cm) & RD (mm) & LBL (cm) \\
\hline Rootstock & & & & \\
Citrandarin 'Indio' & $23.00 \mathrm{a}$ & $23.90 \mathrm{a}$ & $2.88 \mathrm{a}$ & $9.04 \mathrm{a}$ \\
HTR-069 & $10.93 \mathrm{~b}$ & $14.06 \mathrm{~b}$ & $2.15 \mathrm{~b}$ & $8.29 \mathrm{a}$ \\
$\mathrm{LRF} \times(\mathrm{LCR} \times \mathrm{TR})-005$ & $18.96 \mathrm{a}$ & $13.90 \mathrm{~b}$ & $2.22 \mathrm{~b}$ & $7.74 \mathrm{a}$ \\
\hline Crown & & & & \\
'Pera' sweet orange & $17.28 \mathrm{a}$ & $19.73 \mathrm{a}$ & $2.76 \mathrm{a}$ & $10.10 \mathrm{a}$ \\
'Sunki Mandarin' tangerine & $15.87 \mathrm{a}$ & $16.58 \mathrm{a}$ & $2.13 \mathrm{~b}$ & $5.78 \mathrm{~b}$ \\
'Santa Cruz Rangpur' lemon & $16.54 \mathrm{a}$ & $14.58 \mathrm{a}$ & $2.21 \mathrm{~b}$ & $8.48 \mathrm{a}$ \\
\hline
\end{tabular}

Note. Means followed by the same letters did not differ from each other in the Tukey test $(\mathrm{p}<0.05)$.

\section{Discussion}

Fungi incidence, which could have caused the death of some rootstocks in the present study, also happened in minigraftings applied to rubber trees; the adopted procedures helped solving the problem (Lemos Filho et al., 1994). Such measures can be applied to citrus minigrafts in order to minimize this issue and to increase survival rates, besides the one recorded in the current study, which varied from $10 \%$ in 'Clementine' tangerine minigrafted onto citrandarin 'Riverside' when apical segment size was assessed in minigrafting success (Table 1) to $73.33 \%$ in 'Santa Cruz Rangpur' lemon onto hybrid HTR-069 in a study combining rootstock and citrus crowns (Table 4). 
Apical segment mortality can be related to adaptations, since the assessed segments were generated in laboratory environment presentingcontrolled temperature and luminosity. Cultivation in vitro was performed under good assepcy and nourishment conditions. However, rootstock mortality was likely caused by initial water stress and by inappropriate apical segment positioning between the two parts (apical segment and rootstock) (Lemos Filho et al., 1994).

Another factor to be considerate into account is the compatibility between involved tissues given their great influence on the success of overall grafting techniques. This factor also has to be considerate into account, since it relates the affinity between crown and rootstock (Campos et al., 2017). Overall, this is an important factor to achieve a successful grafting.

Such compatibility is determined by the adherence between rootstock and crown cultivars, which is divided into three phases: callus formation and contact between the exchange regions of the two tissues; differentiation of parenchymal cells from the callus in the new exchange cells, which connect the exchanges in these two tissues and the formation of phloem and xylem continuity. This last phase is fundamental to achieve a successful grafting (Hartmann et al., 2011; Pina et al., 2012; Alexandre et al., 2013). The present study did not show callus formation in minigrafted plants that did not present successful adherence, which evidenced lack of connection between tissues. Without these processes, there is no adherence between the two parts, and it is featured as imcompatibility. In nogueira, Farsi et al. (2016) observed that the late and limited differentiation of vascular elements and the establishment of weak vascular connections between rootstock and crown were the events most clearly characterizing incompatible individuals. However, there is no report in the literature corroborating the lack of compatibility between the involved genotypes.

The size of the herein used apical segment was also a determining factor to accomplish a successful minigrafting Based on results recorded in the present study, $2 \mathrm{~cm}$ long apical segments favored the adherence rates, which were from three to five times higher than those recorded for shorter segments (Table 1). This outcome was corroborated by Lemos Filho et al. (1994), who state that, assumingly, longer apical segments help water balance in the rootstock and graft adherence. The existence of more tissues for photoassymilate accumulation in longer apical segmnets might have favored their development (Oliari et al., 2016). According to Fachinello, Hoffmann e Nachtigal (2005), larger carbohydrate stocks may have related to higher survival rates. Lemos Filho et al. (1994) noticed that carbon stocks in the bulbs of rubber trees contributed to the continuity of breathing processes in the tissues, besides boosting the development of scar callus and the expansion of minigrafted plants. Starch hydrolysis and mobilization in association with endogenous auxin levels in the meristematic region of the graft apices could have been responsible for improvements in the minigrafting procedure adopted for yellow passion fruit in P. mucronata Lam (Oliari et al., 2016).

Responses from the interaction between rootstock and crown change, depending on the genotype and on the compatibility between the two parts, as it can be seen in the present study (Table 6 and 8). According to Pina et al. (2012), these responses will involve several structural, biochemical and physiological interactions between these tissues. Hayashi et al. (2012) assessed the grafting technique in different citrus genotypes and pointed out higher bulb formation rates in 'Valencia' orange grafted onto 'Santa Cruz Rangpur' lemon (98\%), when it is compared to citrus 'Swingle' $(66.70 \%)$ at 49 days measured with photodegradable tape.

The highest adherence rate recorded in the present study was 73.33\% for HTR-069 onto 'Santa Cruz Rangpur' lemon, but variations could be observed in the adherence rates recorded for the other genotypes. These variations could be related to higher and lower compatibility degree between the tested garfts and minigrafts. Oliveira, Damião Filho and Carvalho (2002) also found variations in adherence by $34.37 \%$ and $79.16 \%$ in grafts with 'Valencia' orange cultivars budded onto plantlets of 'Santa Cruz Rangpur' lemon, citrus 'Troyer', 'Cleopatra' orange, trifoliate 'Davis A' and citrumelo 'Swingle'. Accordingly, the minigrafting technique can lead to adherence rates similar to those observed through conventional minigrafting, in which the combination between genotypes will lead to different responses. Minigrafting will present advantages such as multiplication of tripoid varieties generated in vitro at shoter time and propagation of pathogen free material.

With regard to the herein assessed rootstocks, citrandarin 'Indio' recorded the highest means for crown development (Table 6). Passos, Soares Filho and Cunha Sobrinho (2011) highlighted the high vigor of the rootstocks of citrandarin 'Indio', and it may have favored better development in grafted crown variables. On the other hand, as it was observed in the present study for the other hybrids involving 'Trifoliate', Soares et al. (2015) also found that hybrid HTR-069 reduced the size of crowns grafted onto it. Such behavior can be attributed to genetic characterists like low vigor of trifoliate and of some hybrids reported by Fochesato et al. (2007). 
Rootstocks affect the vigor of crown varieties and, therefore, they are related to the genotype; thus, rootstocks induce remarkable differences in crown size (Silva et al., 2012).

Silva et al. (2012) associate rootstock diameter with compatibility between crown and rootstock; they state that this variable indicates crown variety adaptatibility to rootstock, since the rootstock will give support and supply water and nutrients absorbed from the soil. The crown will anable the formation of organic composites that will be translocated to other organs, such as the roots. Another studies with grafting have associated rootstock diameter with rootstock survival. Corrêa et al. (2010) and Santos et al. (2016) worked with passion fruit, Passiflora alata and passion fruit tart rootstocks, respectively, and identified high survival rate. They attributed this result to the crown rootstock relationship, since the higher the survival rate, the larger the crown diameter and the bigger the rootstock. Similar results were observed in citrus minigrafts, because overall, the crown diameter and rootstock relation varied from $2.13 \mathrm{~mm}$ to $2.88 \mathrm{~mm}$.

Variety 'Pera' sweet orange stood out in rootstock diameter, because it presented higher means in this variable (Table 6), different from what Campos et al. (2017) have observed 120 days after minigrafting applied to guava, when rootstock diameter was similar in all combinations involving crown cultivar and rootstock.

Shoot area monitoring is an important instrument to assess physiological characteristics related to plant growth, to photosynthetic relations and to transpiration processes, as well as a useful index to assess damage caused by diseases and leaf plagues (Monteiro et al., 2005). The present study did not show any relation between leaf balde length and rootstock development, since there was no statistical difference between rootstock length in crowns that had recorded the longest and shortest leaf blades (Table 7).

Overall, the callus observed in survival plants (Figure 2) indicates successful minigraft adherence. Pina et al. (2012) observed better plasmodesmal coupling in cells of calluses in the grafted region in Prunus spp. They state that these cells performed a fundamental role in the rootstock-crown cultivar interaction. The content and nature of cells involved in the graft-union phase can play an important role in triggering responses that lead to the formation of strong and well-succeeded bonds between the two individuals (Farsi et al., 2016).

Rootstocks were $19.73 \mathrm{~cm}, 16.58 \mathrm{~cm}$ and $14.58 \mathrm{~cm}$ long 120 days after minigrafting in 'Pera' sweet orange, 'Sunki Mandarin' tangerine and 'Santa Cruz Rangpur' lemon, respectively (Table 6). According to Hayashi et al. (2012) the least height essential for seedlings' trading is $30 \mathrm{~cm}$. This height was already reached by more than $50 \%$ of 'Pera' sweet orange and 'Sunki Mandarin' tangerine.

As herein observed, 4 months is the advantajous time to get seedlings through conventional grafting; according to Carvalho, Graf and Violante (2005) it is necessary to have from 3 to 5 months after grafting in order to have seedlings good for trading. With respect to micrografting, this advantage is even better, since this technique requires plant acclimation after adhresion in plants micrografted in vitro.

Overall, the herein proposed citrus minigrafing procedure based on apical segments generated in vitro, is effective and leads to crown bond to rootstock, as well as to growth.

\section{References}

Alexandre, R. S., Lopes, J. C., Tiradentes, A. T., Bruckner, C. H., \& Otoni, W. C. (2013). Metodologia de minienxertia em maracujazeiros. Revista Brasileira de Fruticultura, 35(1), 329-332. https://doi.org/ $10.1590 / \mathrm{S} 0100-29452013000100040$

Andrade, R. A., \& Martins, A. B. G. (2003). Propagação vegetativa de porta-enxertos para citros. Revista Brasileira de Fruticultura, 25(1), 134-136. https://doi.org/10.1590/S0100-29452003000100038

Campos, G. S., Marinho, C. S., Portella, C. R., Amaral, B. D., \& Carvalho, W. S. G. de. (2017). Production of guava mini-grafted on intra or interspecific rootstock. Revista Brasileira de Fruticultura, 39(1), 630-635. https://doi.org/10.1590/0100-29452017635

Carlos, E. F., Stuchi, E. S., \& Donadio, L. C. (1997). Porta-enxertos para a citricultura paulista. Boletim Citrícola, 11, 47. Jaboticabal: Funep, Brasil.

Carvalho, S. A., Graf, C. C. D., \& Violante, A. R. (2005). Produção de material básico e propagação. In D. M. Junior, J. D. Negri, R. M. Pio, \& P. P. Junior (Eds.), Citros (pp. 281-316). Instituto Agronômico de Campinas, Fundag: Campinas, Brasil.

Chae, C. W., Yun, S. H., Park, J. H., Hyun, J. W., Koh, S. W., \& Le, D. H. (2013). Micrografting and heat treatment combination for eliminating virus of CTV-infected Citrus. Journal of Life Science, 23(2), 267-272. https://doi.org/10.5352/JLS.2013.23.2.267 
Corrêa, L. S., Cavichioli, J. C. C., Oliveira, J. C., \& Boliani, A.C. (2010). Uso de câmara úmida em enxertia convencional de maracujazeiro-amarelo sobre três porta-enxertos. Revista Brasileira de Fruticultura, 32(2), 591-598. https://doi.org/10.1590/S0100-29452010000200033

Cunha Sobrinho, A. P. da, Passos, O. S., Soares Filho, W. dos S., \& Girardi, E. A. (2013). Propagação. In A. P. da Cunha Sobrinho, A. F. de J. Magalhães, A. da S. Souza, O. S. Passos, \& W. dos S. Soares Filho (Eds.), Cultura dos citros (pp. 322-345). Embrapa: Brasília-DF, Brasil.

Ewens, M., \& Felker, P. (2003). The potential of mini-grafting for large scale comercial production of Prosopis alba clones. Journal of Arid Environments, 55(2), 379-387. https://doi.org/10.1016/S0140-1963(03)00039-9

Fachinello, J. C., Hoffmann, A., \& Nachtigal, J. (2005). Propagação vegetativa por estaquia. In J. C. Fachinello (Ed.), Propagação de plantas frutíferas (pp. 69-109). Embrapa Informação Tecnológica: Brasília, DF, Brazil.

Farsi, M., Moghadam, M. F., Zamani, Z., Hassani, D., \& Ahmadi, A. (2016). The histology of minigrafting of Persian walnut trees cv. Chandler. International Journal of Horticultural Science and Technology, 3(2), 167-177.

Ferreira, D. F. (2011). Sisvar: A computer statistical analysis system. Ciência e Agrotecnologia, 35(6), 1039-1042. https://doi.org/10.1590/S1413-70542011000600001

Fochesato, M. L., Souza, P. V. D., Schafer, G., \& Maciel, H. S. (2007). Crescimento vegetativo de porta-enxertos de citros produzidos em substratos comerciais. Ciência Rural, 37(4), 970-975. https://doi.org/10.1590/ S0103-84782007000400008

Hartmann, H. T., Kester, D. E., Davies Junior, F. T., \& Geneve, R. L. (2011). Plant propagation: Principles and practices (8th ed.). Prentice Hall: New Jersey, EUA.

Hayashi, S., Girardi, E. A., Silva, S. R., Stuchi, E. S., \& Cantuarias-Avilés, T. (2012). Avaliação de fita fotodegradável para enxertia em mudas de citros. Revista Brasileira de Fruticultura, 34(2), 641-645. https://doi.org/10.1590/S0100-29452012000200042

Kalil Filho, A. N., Hoffmann, H. A., \& Tavares, F. R. (2001). Mini-garfagem: Um novo método para a enxertia do mogno sul-americano (Swietenia macrophylla King), Comunicado Técnico, 62, 4. Embrapa Florestas: Colombo, PR, Brasil.

Lemos Filho, J. P., Pereira, J. P., Medrado, M. S., Costa, J. D., \& Pinto, H. S. (1994). Minienxertia da seringueira (Hevea spp.): problemas e avanços na técnica. Pesquisa Agropecuária Brasileira, 29(5), 779-784.

Lloyd, G., \& Mccown, B. (1980). Use of microculture for production and improvement of Rhododendron spp. HortScience, 15, 416-417. https://doi.org/10.1016/0090-4295(80)90485-9

Monteiro, J. E. B. A., Sentelhas, P. C., Chiavegato, E. J., Guiselinei, C., Santiago, A. V., \& Prela, A. (2005). Estimação da área foliar do algodoeiro por meio de dimensões e massa das folhas. Bragantia, 64(1), $15-24$. https://doi.org/10.1590/S0006-87052005000100002

Navarro, L., Roistacher, C. N., \& Murashige, T. (1975). Improvement of shoot-tip grafiting in vitro for virus-free Citrus. Journal of the Americam Society for Horticulturae Science, 100(5), 471-479.

Ohta, S., Kuniga, T., Nishikawa, F., Yamasaki, A., Endo, T., Iwanami, T., \& Yoshioka, T. (2011). Evaluation of novel antiviral agents in the elimination of Satsuma dwarf virus (SDV) by semi-micrografting in Citrus. Journal of the Japanese Society for Horticultural Science, 80(2), 145-149. https://doi.org/10.2503/ jjshs1.80.145

Oliari, L. S., Giles, J. A. D., Mayrinck, L. G., Oliveira, J. P. B., Lopes, J. C., Otoni, W. C., ... Alexandre, R. S. (2016). Mini-grafting of adult Passiflora edulis Sims f. flavicarpa Deg. scions onto vegetatively propagated adult rootstocks of P. mucronata Lam. Australian Journal of Crop Science, 10(4), 490-496. https://doi.org/ 10.21475/ajcs.2016.10.04.p7156x

Oliveira, I. V. M., Damião Filho, C. F., \& Carvalho, S. A. (2002). Enxertia em citros por substituição de ápice caulinar. Revista Brasileira de Fruticultra, 24(3), 744-747. https://doi.org/10.1590/S0100-294520020003 00046

Passos, O. S., Soares Filho, W. Dos S., \& Cunha Sobrinho, A. P. da. (2011). Citrandarin 'Índio': Nova opção de porta-enxerto para a citricultura brasileira. Embrapa Mandioca e Fruticultura, Cruz das Almas, BA, Brazil. Retrieved from http://www.infoteca.cnptia.embrapa.br/infoteca/handle/doc/919343 
Pina, A., Errea, P., Schulz, A., \& Martens, H. J. (2012). Graft union formation and cell-to-cell communication via plasmodesmata in compatible and incompatible stem unions of Prunus spp. Scientia Horticulturae, 143, 144-150. https://doi.org/10.1016/j.scienta.2012.06.017

Sanabam, R., Singh, N. S., Handique, P. J., \& Devi, H. S. (2015). Disease-free khasi mandarin (Citrus reticulata Blanco) production using in vitro microshoot tip grafting and its assessment using DAS-ELISA and RT-PCR. Scientia Horticulturae, 189, 208-213. https://doi.org/10.1016/j.scienta.2015.03.001

Santos, C. H. B., Cruz Neto, A. J., Soares, T. L., Oliveira, E. J., Jesus, O. N., \& Girard, E. A. (2016). Porta-enxertos e fixadores de enxerto para enxertia hipocotiledonar de maracujazeiro azedo. Ciência Rural, 46(1), 30-35. https://doi.org/10.1590/0103-8478cr20140154

Silva, F. V., Soares, F. A. L., Gheyi, H. R., Travassos, K. D., Suassuna, J. F., \& Cardoso, J. A. F. (2012). Produção de citros irrigados com água moderadamente salina. Irriga, 1(1), 396-407. https://doi.org/ 10.15809/irriga.2012v1n01p396

Soares, L. A. A., Brito, M. E. B., Fernandes, P. D., Lima, G. S., Soares Filho, W. dos S., \& Oliveira, E. S. (2015). Crescimento de combinações copa-porta-enxerto de citros sob estresse hídrico em casa de vegetação. Revista Brasileira de Engenharia Agrícola e Ambiental, 19(3), 211-217. https://doi.org/10.1590/ 1807-1929/agriambi.v19n3p211-217

Wendling, I. \& Hoffmann, H. A. (2005). Minienxertia em casa de vegetação: nova metodologia para propagação vegetativa de Ilex paraguariensis-Resultados Preliminares. Comunicado Técnico, 132 (p. 6). Embrapa Florestas: Colombo, PR, Brazil.

\section{Copyrights}

Copyright for this article is retained by the author(s), with first publication rights granted to the journal.

This is an open-access article distributed under the terms and conditions of the Creative Commons Attribution license (http://creativecommons.org/licenses/by/4.0/). 